\title{
9.5 college credit fiber optic training program for under- and unemployed women: a private/public/continuing education partnership designed to promote women in fiber optics as a workforce initiative
}

Margaret Stroup, Marjorie Valentin, Randall Seebeck, Joseph Williams, Deborah Jeffers, et al.

Margaret H. Stroup, Marjorie R. Valentin, Randall G. Seebeck, Joseph Williams, Deborah Jeffers, Robert Markoja, "9.5 college credit fiber optic training program for under- and unemployed women: a private/public/ continuing education partnership designed to promote women in fiber optics as a workforce initiative," Proc. SPIE 4588, Seventh International Conference on Education and Training in Optics and Photonics, (28 May 2002); doi: $10.1117 / 12.468693$

SPIE Event: Education and Training in Optics and Photonics 2001, 2001, Singapore, Singapore 


\title{
9.5 College Credit Fiber Optic Training Program for Under-and Unemployed Women: A Private/Public/Continuing Education Partnership Designed to Promote Women in Fiber Optics as a Workforce Initiative
}

\author{
AUTHOR LISTING \\ Margaret H. Stroup*, Marjorie R. Valentin*, Randy Seebeck*, Joseph Williams**, \\ Deborah Jeffers**, Robert Markoja***
}

\begin{abstract}
Three Rivers Community College, in conjunction with CiDRA Corporation a fiber-optic telecommunication company and Middlesex Community College, offered a 12 week, 9.5 college credit Fiber Optics training program for 14 unemployed and underemployed women in central Connecticut. Classes were held at the Meriden Center of Middlesex Community College, with some laboratory activities held at CiDRA's headquarters in Wallingford. Connecticut photonics related manufacturing companies project a need to hire anywhere from 100 to 1000 new photonics workers over the next several years. Despite this incredible demand, Three Rivers Community College is the only community college to offer an associate degree program in Photonics Engineering Technology in Connecticut, and one of only two colleges in New England.
\end{abstract}

Funded in part by monies targeting Non-Traditional Occupations for women through the Connecticut Department of Labor, this accelerated program enabled participants to learn industry basics, be interview ready, and earn valuable credit towards an associate degree. The goal of the training program is to provide these former waitresses, truck drivers, certified nurse aides and medical technicians an opportunity to enter the higher-paying field of fiber-optic technology. The course, designed with curriculum assistance from Connecticut companies, will provide education and training needed to qualify for an entry-level position in fiber-optic manufacturing.

In addition to free tuition, students enrolled in the program received all supplies needed for the course including textbooks, a scientific calculator and an optics experiment kit. Students also practiced fiber termination and splicing skills and were eligible to take the Fiber Optic Association Certification Test at the conclusion of the program. The cost for the test was also paid by the grant. Students met regularly with female employees of CiDRA who served as mentors for the 12-week program. Math and science tutoring was provided by Middlesex Community College as well as basic employability skills and job search skills. CiDRA interviewed all participants who successfully complete the program. All students will complete pre- and post-tests in Math, Photonics, and Fiber Optics in addition to receiving grades for the courses.

\section{KEYWORDS}

Fiber-Optic Manufacturing; Women; Community College

\section{BACKGROUND}

Three Rivers Community College offered a 12-week, 9.5 credit, training program in Photonics that enabled low-income women with an interest in nontraditional careers to obtain entry-level positions as technical production workers in the growing field of fiber optics. The fiber-training program targeted economically disadvantaged women who were unemployed or underemployed. Nontraditional careers are defined as those in which women make up less than $20 \%$ of the workforce. Women, who are most often the only wage earners in single-parent families, constitute nearly $50 \%$ of the nation's labor force. Yet, they are working mainly in a narrow range of occupations and earn on average 60 cents (white 
women, 69 cents, African American women, 58 cents, Latina women, 54 cents) for every dollar earned by a man doing comparable work. ${ }^{1}$ Forty-one percent of all African-American women who work in the service sector work as chambermaids, welfare service aides, cleaners, or nurse's aides; and Latina women are disproportionately working in low-paying factory jobs. ${ }^{2}$ Despite the tremendous demand for trained photonics and fiber technicians estimated to increase from 350,000 in 1994 to $740,000^{* * *}$ by the end of this year, Three Rivers is the only community-technical college to offer an Associate Degree in Photonics education in New England, and has been doing so successfully since 1997. Additionally, Three Rivers, along with the New England Board of Higher Education, received a $\$ 493,000$ grant from the National Science Foundation's Advanced Technology Education Program. Project PHOTON will train teachers throughout New England to teach photonics topics to high school students. ${ }^{* * *}$ The estimate of 740,000 workers made in 1994 turned out to be way too low (Stephanie Weiss, executive editor, Photonics Spectra).

The Fiber Optics Certificate Program was similar to the PHOTON program design. It was a twelve-week 9.5 credittraining program in the field of fiber optics and photonics. Credits earned for this certificate program can be applied towards an associate degree in the College of Technology or the General Engineering Technology programs. Students in the training program became familiar with the basic optical, laser, and fiber-optic principles identified in a recent CONN/STEP study as being necessary for entry-level fiber optic/photonics workers. The program coordinator worked with students to develop the skills necessary to prepare a resume, identify community resources, such as the One-Stop Career Centers and the Connecticut Department of Labor, and secure and retain positions paying well above the minimum wage. Moreover, Three Rivers continues to work closely with several of the fiber optic, telecommunications, and optical companies who are actively seeking our graduates. Specifically, they are, JDS Uniphase, Zygo, and CIDRA, who wrote a strong letter of support, which is included in this packet.

\section{PROGRAM OUTCOMES}

\begin{tabular}{|l|l|l|l|l|l|l|}
\hline $\begin{array}{l}\text { Training/Service } \\
\text { Component(s) }\end{array}$ & $\begin{array}{l}\text { Number } \\
\text { Participants } \\
\text { Served }\end{array}$ & $\begin{array}{l}\text { Number } \\
\text { Participants } \\
\text { Complete } \\
\text { Program }\end{array}$ & $\begin{array}{l}\text { Number } \\
\text { Participants } \\
\text { Placed * }\end{array}$ & $\begin{array}{l}\text { Projected } \\
\text { Average } \\
\text { Starting } \\
\text { Rate of Pay }\end{array}$ & $\begin{array}{l}\text { Projected } \\
\text { Average } \\
\text { Cost } \\
\text { Per } \\
\text { Participant }\end{array}$ & $\begin{array}{l}\text { Projected Average } \\
\text { Cost Per Placement* }\end{array}$ \\
\hline $\begin{array}{l}\text { 12-week Fiber-Optic } \\
\text { training program } \\
(9.5 \text { college credits })\end{array}$ & 20 & 10 & 8 & $\$ 13.00 / \mathrm{hr}$. & $\$ 1,141.20$ & $\$ 2,853.00$ \\
\hline
\end{tabular}

*In program related unsubsidized employment

\section{METHODOLOGY}

This fiber-optic training program focused exclusively on recruiting women as participants. The fiber-optic industry, now experiencing tremendous growth in all regions of the state, meets the challenges presented in the Workforce Investment Board's Regional Needs Assessment. "The demand for this (fiber optic) technology is so great that the suppliers cannot keep up with the demand," said J. Bruce Robinson, President and CEO of Zygo, in a July 29, 2000 Hartford Courant article. The program will target economically disadvantaged women who are either under- or unemployed. Some of the women who are recruited for participation in the program may be TANF recipients who are transitioning out of the program.

Field trips to fiber/optic companies, who support the grant training, were scheduled for Friday afternoons. The free periods on Monday (9-4) and on Wednesday (1-2) were used for individual tutoring sessions. Participants received information on course content, academic requirements for completion, ancillary services, childcare, transportation, etc.) career counseling and financial aid.

During the first week of classes, students were assigned to a peer tutor. Peer tutors worked with small groups, reinforcing information learned in class. Three Rivers' tutors worked up to 19 hours per week, reserving adequate time to assist at-risk students. Students signed up with peer tutors during lunch, and at other times by special arrangement. Peer 
tutors were available to meet with students at least one evening per week to accommodate those students whose family schedules do not allow them at other times. During the twelve weeks of the training, students attended structured workshops facilitated by a Three Rivers' Career Counselor, where they learned interview skills, and how to write an effective resume.

The primary instructors taught the program participants in the following topics: Introduction to Photonics and Lab; and Introduction to Fiber Optics and Lab. Additional, staff taught the Computer Applications course/Lab, as well as assisted in the career counseling process. Field trips were conducted on Fridays, so that students could "shadow" working professionals in the field.

Three Rivers has the only Photonics Associate degree program in all of New England. Students were given optical fiber and supplies to make six to eight fiber optic jumper cables, in order to learn fiber-handling techniques. They received course texts, and resource materials on the fiber optics industry. Content will include an introductory course PHO $115 / 116$, on sources and nature of light, ray optics, and wave optics, and a course PHO 124 on telecommunications and telecommunications manufacturing. Basic algebra was used in this portion of the training. In PHO 121, the fiber optic course, students learn the basics of fiber optics including how fiber works, types of fiber and cable and their uses, fiber measurements, fiber termination, components, installation and testing.

Students had the opportunity to visit telecommunications manufacturers to observe the processes in action, theory into practice. As part of this overview of photonics technology, students were studied basic topics in vision and laser safety for manufacturing, medical and telecommunication applications. Students introduced to and become proficient in work processing, spreadsheets, and a database management system. Finally, students learned the practical skills necessary to begin a dynamic career in the photonics/fiber optic industry. Student completers were eligible for the Fiber Optic Association Level I certification test. This certificate is extremely valuable to employers, since it is indicative that the applicant has gone the extra step to apply for certification. Three Rivers' faculty utilizes classroom methods that encourage women and girls to pursue careers in non-traditional career fields such as fiber optics.

\subsection{FIBER OPTICS CERTIFICATE CURRICULUM}

$\begin{array}{lll}\text { PHO } 115 / 116 & \text { Introduction to Photonics } & 4 \text { CREDITS } \\ \text { PHO } 105 & \text { Laser Safety } & .5 \text { CREDITS } \\ \text { PHO } 121 & \text { Introduction to Fiber Optic Technology } & 4 \text { CREDITS } \\ \text { CSC } 103 & \text { Computer Class } & 1 \text { CREDITS } \\ \text { TOTAL CREDITS } & & \mathbf{9 . 5} \text { CREDITS }\end{array}$

The program coordinator, in addition to the Directors of Continuing Education, and Business and Industry Services, will recruit students through several sources. Mailings were sent to area social service agencies, the State Department of Social Services and Labor, adult education sites throughout southeastern Connecticut, and to local media sources. College personnel facilitated information sessions at the One-Stop Career Center in New Britain. All students completed placement testing to determine their level of competence in mathematics. Students were encouraged to take advantage of tutoring resources, where they reviewed the algebra skills they need to successfully complete the program. Students identified, as needing significant remedial instruction in reading and basic algebra, received additional tutoring as indicated. Three Rivers has a solid commitment to providing support services necessary to ensure a student's success. After exposing 20 women to the program, 10 were selected to participate in the program.

The computerized basic skills Placement Test, which all 12 of Connecticut's Community Colleges utilize, was used to assess the interested participants knowledge levels in both reading and basic math and basic algebra. Through advertising via social service agencies and the media, prospective participants self-selected for participation in the program. Relevant skill areas, which might determine aptitude, include everything from prior manufacturing experience, to quilting/needlework and waitress work. In point of fact, during meetings with representatives of JDS Uniphase, they indicated that they were having the most success in recruiting/training/retaining employees who had prior work experience as waitresses, and no fiber optic background. 
Additionally, students requiring either transportation or reimbursement for transportation received information and monetary assistance so that they may attend all classes and field trips. The College provided transportation vouchers for students in need. All of our students received tutoring or counseling assistance to successfully complete the program. In fact, job/career counseling was an integral component to the curriculum.

Three Rivers collaborated extensively with the following agencies/organizations to ensure the successful implementation of the program. They include, but are not limited to, the Departments of, Labor; Social Services; Transportation; TVCCA; the One-Stop Centers, in both Norwich and New London; The Women's Center of Southeastern Connecticut; Women in Construction; the Connecticut Women's Education and Legal Fund; the Permanent Commission on The Status of Women; in addition to many smaller, local social service agencies, such as Madonna Place; the Thames River Family Program; and Catholic Charities. We will also attempt to recruit some of our current female students who might fulfill the criteria and who have expressed interest in the technology fields.

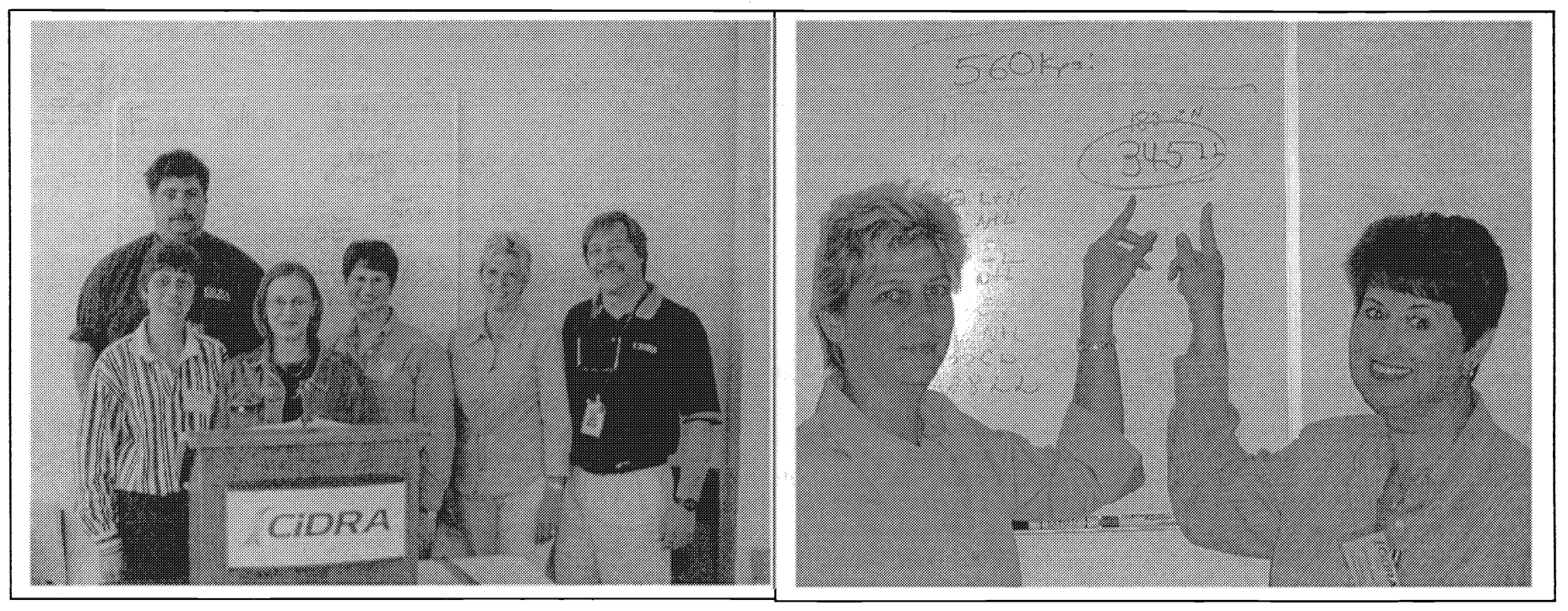




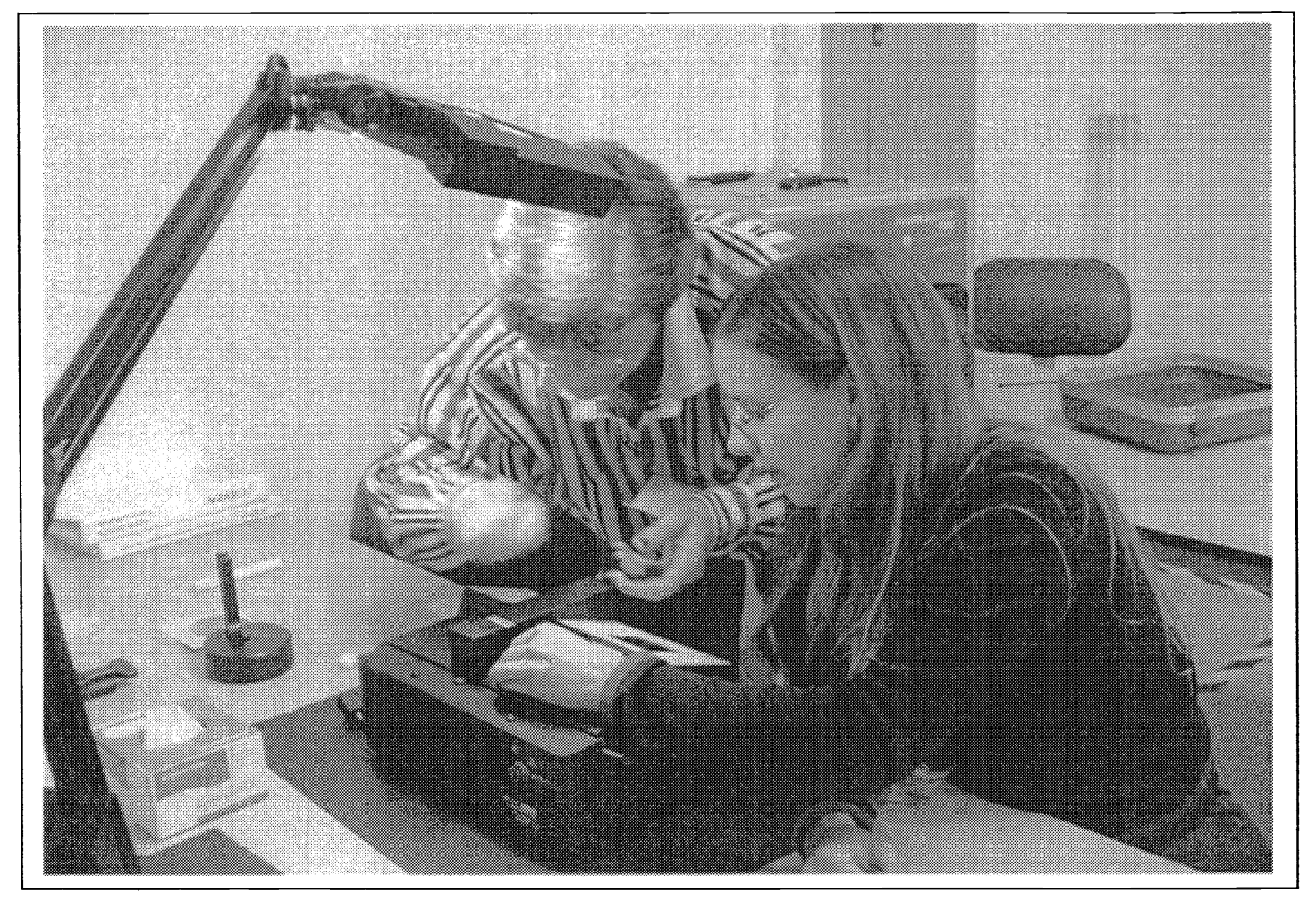

Students practiced their fusion splicing techniques at CiDRA Laboratories

\section{TRAINING SERVICES}

\begin{tabular}{|l|l|l|l|l|l|l|l|l|l|l|l|l|}
\hline Training/Services* & July & Aug. & Sept. & Oct. & Nov. & Dec. & Jan. & Feb. & March & April & May & June \\
\hline Outreach/Recruitment & $0 / 0$ & $0 / 0$ & $0 / 0$ & $0 / 0$ & $40 / 20$ & $40 / 20$ & & & & & & \\
\hline Assessment Orientation & & & & & & & 20 & & & & & \\
\hline Training & & & & & & & & 10 & 10 & 8 & & \\
\hline Tutoring/Counseling & & & & & & & 20 & 10 & 10 & 10 & 8 & \\
\hline Placement & & & & & & & & & & & 4 & 4 \\
\hline Follow-Up & & & & & & & & & & & 4 & 4 \\
\hline
\end{tabular}

*E.g. Outreach, Assessment, Orientation, Training, Counseling, Placement, Follow-up, Etc. 


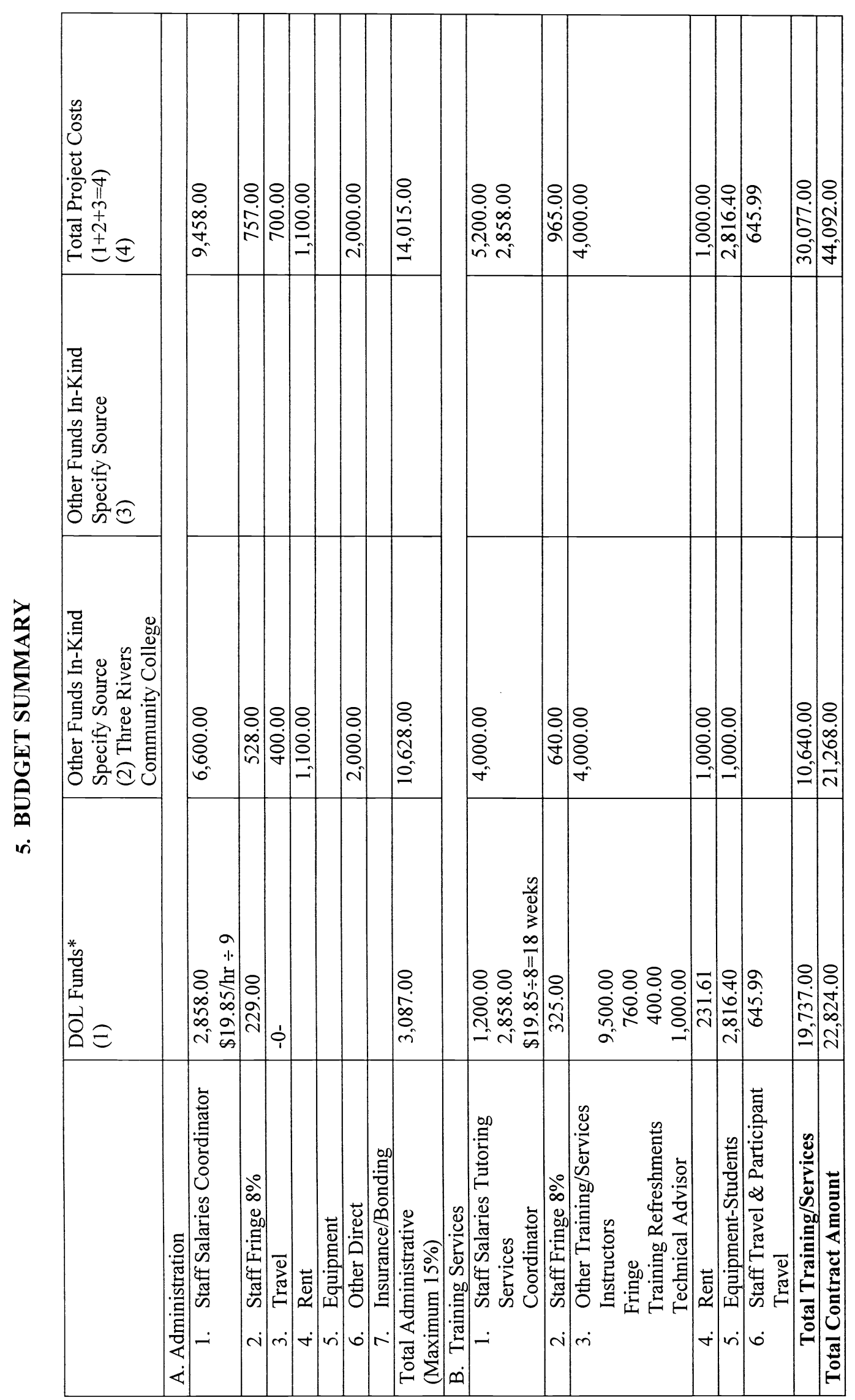


6. DATA

MATH PRE \& POST TEST SCORES

\begin{tabular}{|c|l|l|}
\hline & Pre-Test 3/01 & Post-Test 6/01 \\
\hline Student A & 19 & 16 \\
\hline B & 11 & 21 \\
\hline C & 18 & Unknown \\
\hline D & 4 & 12 \\
\hline E & 16 & 17 \\
\hline F & 9 & 33 \\
\hline G & 20 & 32 \\
\hline H & 12 & 22 \\
\hline
\end{tabular}

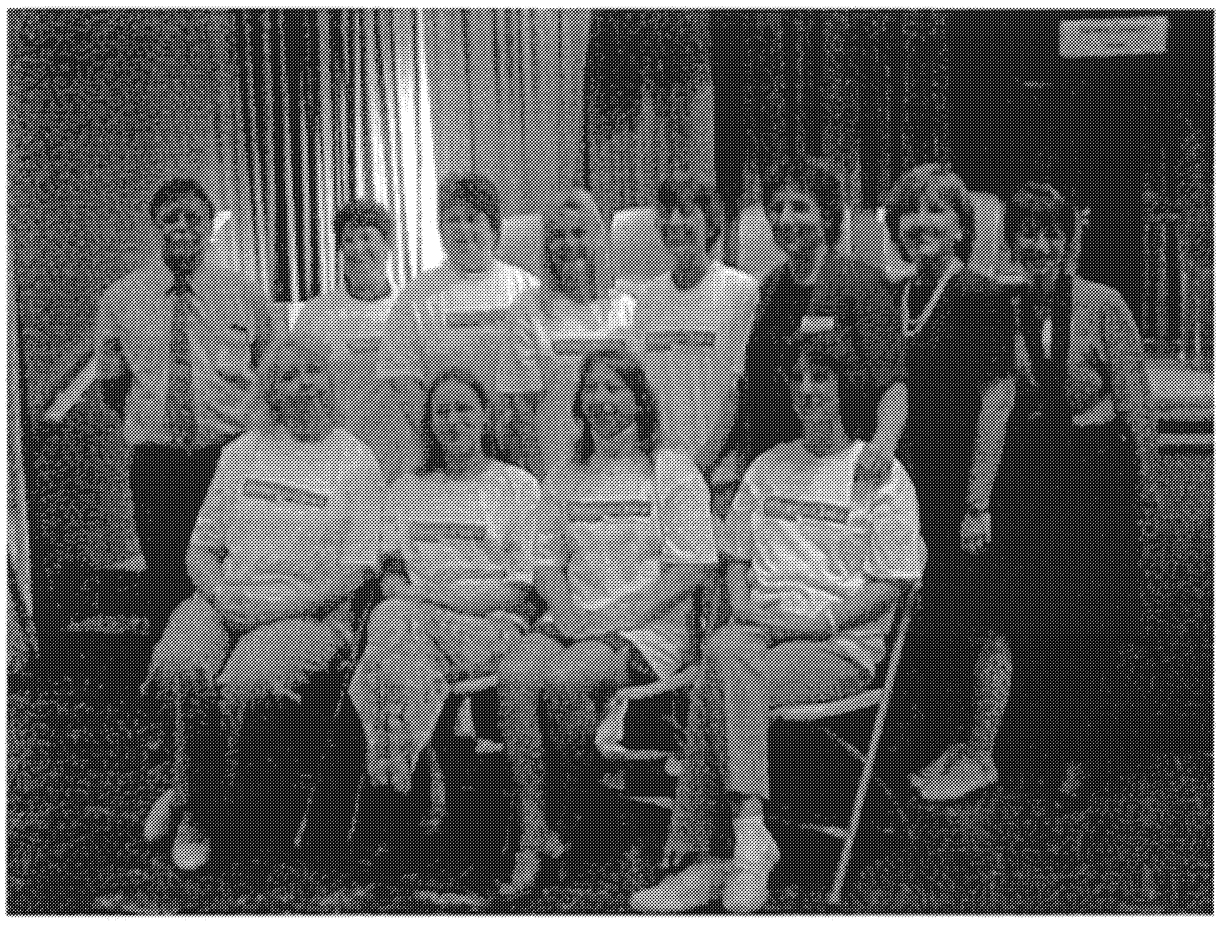

The eight students wearing their "Women in Optics" tee-shirts on graduation day. Also present, were Professors Donnelly, Seebeck, Program Coordinator, Peg Stroup and Eleanor Lennon, Non-

Traditional Occupations Coordinator for the Connecticut Department of Labor.

\section{ACKNOWLEDGEMENTS}

Three Rivers Community College wishes to acknowledge the Connecticut State Department of Labor for their funding of this program. The Connecticut DOL provided over $\$ 23,000$ to support this endeavor. The money covered the tuition, fees, books, supplies, and instruments for all of the students. The funding also provided for food at the graduation ceremony at the successful conclusion of the program in June 2001.

Three Rivers Community College also acknowledges the support of CiDRA Corporation and Middlesex Community College. This program was a true collaboration between industry and higher education to provide under and unemployed women with the skills and knowledge to enter the higher paying careers in fiber optics technology. CiDRA 
provided an opening kick-off tour and luncheon for the students and state officials who were responsible for funding the program. Additionally, CiDRA provided technical expertise and "mentors" for the students throughout the program. The students participated in labs on-site at CiDRA, and were mentored by female CiDRA employees.

Middlesex Community College provided tutoring in math and scientific notation for the duration of their program in addition to teaching the one-credit computer class. Middlesex also provided the classroom and lab space for all of the courses taught as part of the program at their centrally located Meriden center.

The One-Stop Center in Meriden, Connecticut, part of the Connecticut DOL, assisted with recruiting the students who enrolled in the program. They passed out program information, provided a room to meet with prospective students and helped administer the math pre-test. The Connecticut DOL staff also did a presentation on resume writing and helped the students post their completed resumes on the web. Other customized topics presented were "Dress for Success", and interviewing skills.

\section{SUMMARY}

In summary, out of the sixteen initial applicants for the program, eight women ultimately successfully completed. We conducted a pre and post-test in math of all participants. We expected the women with the highest math pre-test to be the best students and to successfully complete the program. This assumption did not prove to be correct. We recruited 16 unemployed or underemployed women from all walks of life. To our surprise, the only participant with prior fiberoptic experience ended up dropping out of the program. One student did not complete high school, but several had completed a few college courses. Ultimately, the students who scored the highest and the lowest on the math pre-test dropped out of the program. We found that the students' motivation levels, ability to network with their fellow students and their ability to juggle classes and homework with their personal lives were the best predictors of success for the program graduates. Additionally, all of the students received tutoring in math, physics and scientific notation as well as personal and professional counseling. They participated in job search, resumé writing and interviewing workshops with the Connecticut Department of Labor and posted their resumés on the Connecticut Department of Labor website. Unfortunately, the timing of the program completion paralleled the downturn of the fiber optics/telecom industries, which has made job placement difficult.

Student C was ill the day the post-test was given and did not take the test. All 8 of the students received A's and B's for the college courses they completed. All of the post-test scores improved except for student A (she was under great emotional duress during that day due to a divorce hearing). The number of questions was 36 and the questions included basic math up through calculus. Five students took the Fiber Optic Association certification test and all 5 passed the exam.

\section{REFERENCES}

${ }^{1}$ U.S. Department of Labor, Women's Bureau, 1993 Handbook on Women Workers: Trends and Issues (Washington, D.C., 1994)

${ }^{2}$ M. Escutia and M.M. Prieto, Hispanics in the Workforce, Part II: Hispanic Women (Washington, Council of LaRaza, 1988): J. Malveaux, The Economic Status of Black Families in Black Families, ed. By H.P. McAdoo (Newbury Park, Calif.: Sage Publications, 1988).

*Contact Mstroup@trcc.commnet.edu; Mvalentin@trcc.commnet.edu; Rseebeck@trcc.commnet.edu; phone 1-860-885-2608; fax 1860-886-5063; http://www.Continuing_Education@trcc.commnet.edu; Three Rivers Community College, 574 New London Turnpike, Norwich, CT USA 06360. **jwilliams@mx.commnet.edu; phone 1-860-343-5710; fax 1-860-343-5844; djeffers@mx.commnet.edu; phone 1-203-238-6202; fax 1-860-343-5844; http://www.Continuing_Education@mx.commnet.edu ; Middlesex Community College, 100 Training Hill Road, Middletown, CT USA 06457; *** rmarkoja@cidra.com; phone 1-203-265-0035; fax 1-203-697-1061; http://www.cidra.com; CiDRA Corporation, North Barnes Park Road, Wallingford, CT USA 06492. 